\title{
Strategic Design of Chinese Enterprises' Foreign Investment from the Perspective of "Belt and Road"
}

\author{
Jing Zeng ${ }^{1}$ \\ ${ }^{1}$ Nanyang Institute of Technology, Nanyang, Henan, 473004
}

Keywords: Belt and Road; foreign investment; Chinese enterprise

\begin{abstract}
The "Belt and Road" Initiative is a major measure to achieve China's economic transformation and upgrading and lead the new economic normal through a new round of opening-up to the outside world. It is of great significance for further advancing China's new round of opening to the outside world and the common development of countries along the route, and it will also improve foreign investment for Chinese companies. Continuing to promote the "going out" strategy has also brought new historical opportunities for enterprises. This paper interprets the motivation of Chinese companies for foreign investment, the intention of the "Belt and Road" to build the top-level design, the progress of the construction of the "Belt and Road", the problems encountered and the future development trend of Chinese enterprises under the "Belt and Road" construction background, so as to open up domestic and foreign markets, make use of domestic and foreign resources, and realize the mutual benefits and win-win of Chinese enterprises' foreign investment to better participate in global economic governance.
\end{abstract}

\section{Introduction}

For a long time, the topics related to the flow of international capital have been concerned by the research fields of international economics. With the rapid development of foreign investment among developed countries and between developed and developing countries, the flow of international capital presents a brand-new trend. More and more developing countries begin to "go out" for "survival and development". The pace, through a variety of ways to direct investment and indirect investment in developed countries and other developing countries [1]. In this process, many developing countries rely on the "technology-seeking" model of foreign investment to explore their international markets and acquire advanced technologies from developed countries. As the world's second-largest economy, the second-largest foreign investor and the largest trading nation, China plays a key role in the international market for foreign investment. Especially in the context of the country's emphasis on boosting economic growth and optimizing production capacity and industrial structure through supply-side reforms, Chinese companies continue to obtain more valuable tangible assets and value-added capabilities through outward investment in the process of seeking outbound investment routes. Intangible assets, which have important strategic significance for the cultivation of corporate competitive advantages and the promotion of international influence.

\section{The Overall Review of China's Current Foreign Investment}

Driven by various factors, the distribution of foreign investment by Chinese enterprises is relatively concentrated, and the cooperation between energy and mineral resources industries is outstanding. In recent years, foreign investment has always been in a dominant position. It can be seen from the overseas mergers and acquisitions cases of Chinese companies that most of the top mergers and acquisitions belong to the energy and mineral resources industries, and many of the major players are state-owned enterprises, such as the "three barrels of oil" in the petrochemical industry. The reason why such a situation has emerged is that apart from the fact that the country's rapid economic growth has a strong demand for resource formation, it also shows that China's state-owned enterprises are more sensitive to market operations and international competition and are more susceptible to the effects of central policies. In addition, it should be noted that China's 
foreign investment completed in the form of mergers and acquisitions in recent years usually involves a relatively large amount, and is based on the sensitive assets of the host country, resulting in a greater international impact. This aspect has enhanced the influence of China's foreign investment and the international competitiveness of Chinese companies. On the other hand, it has also caused the host country to have doubts about China's foreign investment, and even triggered suspicions from some countries with ulterior motives. Therefore, it is necessary to appropriately avoid the acquisition of such assets when investing overseas, so as not to affect the international influence of the "going out" of Chinese companies. This aspect has enhanced the influence of China's foreign investment and the international competitiveness of Chinese companies. On the other hand, it has also caused the host country to have doubts about China's foreign investment, and even triggered suspicions from some countries with ulterior motives. Therefore, it is necessary to properly avoid the acquisition of such assets when investing overseas, so as not to affect the pace of "going out" of Chinese enterprises [1].

Under the guidance of the "One Belt and One Road" strategy, countries along the route are becoming China's foreign investment hotspots [3]. In the past two years, Chinese enterprises have made direct investments in more than 50 countries and regions along the "One Belt and One Road" with a variety of capital outputs. A large amount of capital has flowed to Russia, Kazakhstan and other countries in Europe and Indonesia and Thailand in Southeast Asia. And other countries. In the process of foreign investment, China's participation in international production capacity cooperation is also actively promoting. This is because many countries have tried to strengthen their international competitiveness and improve people's livelihood by developing their own economy, upgrading their industrial level, and improving infrastructure conditions. Chinese enterprises took advantage of this opportunity to cooperate with many countries and regions in railway operations, power system construction, communication facilities construction and maintenance, and formed a significant competitive advantage in many fields [2]. At the same time, China's industrial advantages and technological advantages accumulated over several decades can be combined with the resource advantages of many countries (especially developing countries) and complemented by resource advantages and technological advantages driven by market economy. For example, in the coming period of time, with the help of China's foreign exchanges, many countries are looking forward to capacity cooperation with China, especially in high-speed rail projects and nuclear power projects, and even more hope to use China's high-end equipment exports and construction to gain more. Infrastructure benefits.

\section{Strategic Choices for Foreign Investment Markets}

The contemporary transnational investment market is mainly concentrated in the developed countries and has formed a three-polarized market of the United States, the European Union, and Japan. According to statistics, they account for approximately 'global investment' (, which accounts for global foreign investment). (. Because of the high concentration of investment markets and the accelerated flow of global capital [3], many market gaps have been created or generated, including Market gaps in investment areas, industries, and technologies. Chinese companies' choice of market strategy in future foreign investment should be to avoid positive market competition with multinational companies in developed countries, and to strive to bring gaps in the market first. Through its breakthroughs, it has accumulated strength and continuously expanded, gradually forming a multi-level and diversified pattern of foreign investment markets.

In choosing this type of outbound investment market strategy, we can also simply summarize it as a "look for gap" strategy. The specific methods also have the following aspects: First, the use of very mature technology and low-cost artificial advantages in resource development in China can be used to invest in the Far East region of Russia and many countries in Africa to develop resources in cooperation. The oil, natural gas, forests, non-ferrous metal ore, and cotton owned by these places are rich in resources and are needed by our country for a long time. Before entering the developed countries, Chinese enterprises should be a key investment market. The second is to make use of the favorable conditions for developed countries to export products to some developing countries. In 
Africa, Latin America and the Middle East, they can choose to invest actively in the processing of primary products and industrial products. And in the developing countries to establish export processing market, its sales market is mainly built in developed countries. Third, the use of international multinational companies to master only the core technology, the market opportunities brought about by the continuous decline of its products made of self-made parts, such as the auto industry General Motors has dropped to 37\%, Mercedes-Benz for 35\%, Toyota and Nissan each 25\%, China Enterprises can produce supporting products at home and abroad based on their own advantages and adopt follow-up investment. By integrating itself into the international production management system of multinational companies, it gains a certain market share in its global market. The fourth is to make use of the domestic industry adjustment and development gap caused by the continuous expansion of developed countries. Chinese enterprises can also go to developed countries to seek opportunities for direct investment. There are investment markets in agriculture, manufacturing, and non-technical service industries. There are various conditions for easy financing and easy access to new technologies [4].

\section{Selection Methods of Foreign Investment}

At this stage, China's outbound investment companies mainly adopt the method of building new overseas companies, and most of them are foreign exchange investments. This single and backward investment method is also one of the major factors restricting the development of China's foreign investment. Contemporary capital output has long been not a simple export of funds. Especially in developing countries such as China, the need to use mature technologies, complete sets of equipment, surplus raw materials, technical software, engineering personnel, and information services is the main source of capital output. To accelerate the international transfer of mature industries in China. To this end, Chinese companies need to adapt to the requirements of global development in their choice of foreign investment methods, adopt a "grab the time" strategy, and try to shorten the time or process of entering the international market. Generally speaking, the choice of foreign investment methods must also consider long-term development. The following three aspects should be emphasized in the selection of specific methods: First, investing in factories in developing countries must be avoided as much as possible. We must make full use of each other's advantages and implement them. The principle of "complementing each other's strengths" must be effective and effective. In particular, in terms of cooperative development of resources, it is necessary to maintain its own advantages and ensure the other's interests. Only in this way can there be long-term cooperation and development. Second, to invest in developed countries, mergers and acquisitions should be adopted. Especially for those small and medium-sized enterprises with specialized technical characteristics, mergers and acquisitions or equity acquisitions should be conducted through foreign financing as much as possible, which not only can reduce investment costs and risks, but also can enter mature markets and foster technological competitive advantages. Third, in order to adapt to the global competition of cross-border investment, Chinese companies also need to intervene in a multinational strategic alliance. According to the British "Economist" report, $90 \%$ of the global multinational companies have joined the alliance. Their participation in strategic alliances is mainly to achieve their objectives of complementing each other, superimposing advantages, and sharing interests. Chinese companies must not be able to escape from the outside, but they should also advance simultaneously in domestic and foreign markets, adopting “market-for-union”, “technology-for-union”, “Resources exchange alliances, etc., As far as possible, participate in strategic alliances of international multinational companies to obtain new sources of interest. The Sino-Fahrenheit exhibition companies are relatively backward in their participation, while the cross-border countries only have to accept the investment funds from the present. Although they have taken it as a late-night event, a major strategic development issue has been proposed and fully understood or assessed. It will give the most powerful policy support to the impact of China's economic development in the 21st century [5]. The development of China's foreign investment will soon be promoted to a new stage. Chinese enterprises' foreign investment must achieve new breakthroughs in its development strategy. Without the government's policy 
support, it is absolutely impossible. The government should introduce a series of preferential policies to encourage enterprises by advancing the "go global" strategy of foreign investment, and gradually establish a comprehensive and systematic legal and policy support insurance system.

\section{Conclusion}

Developing China's foreign investment requires the government to make progress in a planned and planned manner, and it requires comprehensive and multi-level policy support. At present, Chinese companies are in the forefront of both foreign investment and foreign investment, and they are short-term and short-changing, which affects China's economic strength. For this reason, in implementing the "go global" strategy, we must change our concepts, emancipate our minds, establish a clear development goal, and adopt all effective policies and measures to promote the rapid rise of Chinese companies and make them both long-term. Both hands become stronger. Only in this way can Chinese companies win huge international development space for themselves and they will find their place in the wave of economic globalization.

\section{References}

[1] He Xiaoqin. Cross-border mergers and acquisitions and China's foreign investment in the international environment [J]. International Relations Research, 2013,1 (5): 137-150.

[2] Xie Guangya, Cui Jun. An analysis of the external investment model of enterprises based on the perspective of global value chain: Taking Beijing as an example [J]. Theory and Practice of Finance and Economics, 2013, 34(4):50-53.

[3] Zhou Jing, Zhang Limin. The Choice of Foreign Investment Models of Chinese Enterprises in the New Situation [J]. Economic Review, 2015, 31(3): 52-56.

[4] Zhang Na, Qiu Qi. How to avoid the hollowing out of industry in the speed of foreign investment [J]. Decision \& Information, 2015, 32(12):23-26.

[5] Jing Yan. Increased Foreign Investment Urgently Needs to Improve the Legal System [J]. Chinese Administration, 2015, 31(12):34-36 